\title{
Analisis Penilaian Kinerja Organisasi Perangkat Daerah Di Kota Bandung (Studi Kasus Pada Dinas Pemakaman \& Pertamanan; Dinas Kependudukan \& Pencatatan Sipil dan Dinas Pemuda dan Olahraga)
}

\author{
Endah Purnama Sari \\ Fakultas Ekonomi Program Studi Akuntansi-Univ.Kristen Maranatha \\ (Jl. Prof. Drg. Suria Sumantri No. 65, Bandung) \\ endah.psari@yahoo.com \\ Santy Setiawan \\ Fakultas Ekonomi Program Studi Akuntansi -Univ.Kristen Maranatha \\ (Jl. Prof. Drg. Suria Sumantri No. 65, Bandung) \\ santy_jc@yahoo.com \\ Alif Rifky Adilah \\ Fakultas Ekonomi Program Studi Akuntansi -Univ.Kristen Maranatha \\ (Jl. Prof. Drg. Suria Sumantri No. 65, Bandung) \\ alifrifkyy@gmail.com
}

\begin{abstract}
The realization of a good and accountable governance is the hope of all parties. It is expected that the development and implementation of an accountability system that is accurate, clear, legitimate so that the government and development can be carried out efficiently, effectively, cleanly and responsibly and free from corruption, collusion and nepotism (KKN). Based on Speklé and Verbeeten (2013) studies indicating that contractibility moderates the relationship between the use of performance-oriented system performance incentives. The use of performance measurement systems for the purpose of negative incentives affects organizational performance, but this effect is too heavy when Contractibility is high. The type of this research is causal explanatory, and the research sample is population 3 SKPD (Work Unit of Local Area) located in Bandung with data analysis technique using Moderated Regression Analysis (MRA) or interaction test is a special application of linear regression where in regression equation contain Elements of interaction (multiplication of two or more independent variables).
\end{abstract}

Keywords: Performance Appraisal System, Performance, Contractibility, SKPD Bandung, Public Sector

\section{Pendahuluan}

Akuntabilitas Kinerja Instansi Pemerintah adalah perwujudan kewajiban suatu instansi pemerintah untuk mempertanggungjawabkan keberhasilan atau kegagalan pelaksanaan visi dan misi organisasi dalam mencapai tujuan dan sasaran yang telah ditetapkan melalui alat pertanggungjawaban secara periodik. (Laporan Kinerja Instansi Pemerintah Kecamatan Rancasari, 2014). Terwujudnya suatu tata pemerintahan yang baik dan akuntabel merupakan harapan semua pihak. Berkenaan harapan tersebut diperlukan pengembangan dan penerapan sistem pertanggungjawaban yang tepat, jelas, terukur legitimate sehingga penyelenggaraan pemerintah dan pembangunan dapat berlangsung secara berdaya guna, berhasil guna, bersih dan bertanggungjawab serta bebas dari korupsi, kolusi dan nepotisme (KKN).

Sejalan dengan pelaksanaan Undang-undang Nomor 28 tahun 1999 tentang penyelenggaraan negara yang bersih dan bebas dari korupsi, kolusi, dan nepotisme, maka di terbitkan Instruksi Presiden Nomor 7 tahun 1999 tentang Akuntabilitas Kinerja Instansi Pemerintah sebagaimana telah diubah dengan Peraturan Presiden Nomor 29 Tahun 2014 tentang Sistem Akuntabilitas Kinerja Instansi Pemerintah (SAKIP). Definisi dari SAKIP (Sistem Akuntabilitas Kinerja Instansi Pemerintahan) adalah rangkaian sistematik dari berbagai aktivitas, alat dan prosedur yang dirancang untuk tujuan penetapan dan pengukuran, pengumpulan data, pengklarifikasian, pengikhtisaran, dan pelaporan kinerja pada instansi pemerintah, dalam rangka pertanggungjawaban dan 
peningkatan kinerja instansi pemerintah. (Peraturan Presiden Nomor 29 Tahun 2014).

Setiap instansi pemerintah sebagai unsur penyelenggara pemerintahan wajib mempertanggungjawabkan pelaksanaan tugas pokok melalui pelaporan akuntabilitas kinerja instansi pemerintahan. Pelaksanaan dari SAKIP (Sistem Akuntabilitas Kinerja Instansi Pemerintahan) direalisasikan dalam bentuk LAKIP yakni (Laporan Akuntabilitas Kinerja Instansi Pemerintahan) yang berisi laporan realisasi kinerja serta penjelasan tercapainya atau tidak target yang telah direncanakan, perencanaan, pengukuran, serta pelaporan.

Terdapat tiga keuntungan yang akan diperoleh pada saat SKPD (Satuan Kerja Perangkat Daerah) melaksanakan SAKIP (Sistem Akuntabilitas Kinerja Instansi Pemerintahan), yaitu kegunaannya dalam mengukur setiap pembangunan atau kinerja yang dilakukan mereka, sebagai tolak ukur untuk mempertanggungjawabkan anggaran yang telah digunakan untuk pembangunan daerah, serta untuk mendorong terciptanya akuntabilitas kinerja instansi pemerintah sebagai salah satu prioritas untuk terciptanya pemerintah yang baik dan terpercaya (Mukhsin; 2016). Tidak sejalan dengan pernyataan di atas, dalam kenyataannya SAKIP (Sistem Akuntabilitas Kinerja Instansi Pemerintahan) tidak membantu dalam SKPD (Satuan Kerja Perangkat Daerah) seperti yang diharapkan. Hal ini dibuktikan tidak adanya kabupaten/ kota yang bernilai A melainkan hanya 11 kabupaten/kota yang memperoleh nilai B. (Berita CPNS dan Aparatur Sipil Negara; 2015). Berdasarkan penelitian Speklé dan Verbeeten (2013) menunjukkan bahwa contractibility memoderasi hubungan antara penggunaan insentif berorientasi sistem pengukuran kinerja. Penggunaan sistem pengukuran kinerja untuk tujuan insentif negatif mempengaruhi kinerja organisasi, tetapi efek ini terlalu berat ketika Contractibility tinggi.

Berdasarkan latar belakang di atas peneliti ingin mengetahui pengaruh sistem penilaian kinerja terhadap kinerja PNS SKPD (Satuan Kerja Perangkat Daerah) di Kota Bandung dengan variabel mediasi yaitu contractibility.

\section{Kerangka Pemikiran dan Hipotesis}

Perumusan hipotesis dalam penelitian ini terbagi dalam 4 bagian sebagai berikut:

$\mathrm{H}_{1}=$ Terdapat pengaruh antara sistem penilaian kinerja berorientasi insentif terhadap kinerja PNS SKPD di Kota Bandung.

$\mathrm{H}_{2}=$ Terdapat pengaruh antara sistem penilaian kinerja berorientasi eksplorasi terhadap kinerja PNS SKPD di Kota Bandung.

$\mathrm{H}_{3}=$ Terdapat pengaruh antara sistem penilaian kinerja berorientasi insentif terhadap kinerja
PNS SKPD di Kota Bandung yang dimediasi oleh variabel contractibility.

$\mathrm{H}_{4}=$ Terdapat pengaruh antara sistem penilaian kinerja berorientasi eksplorasi terhadap kinerja PNS SKPD di Kota Bandung yang dimediasi oleh variabel contractibility.

\section{Kerangka Teoritis}

Kinerja merupakan suatu wujud perilaku seseorang atau organisasi dengan orientasi prestasi. Kinerja seseorang dipengaruhi oleh beberapa faktor seperti ability, capacity, held, incentive, environment dan validity (Noto Atmojo, 1992 dalam Sutrisno, 2007).

Adapun ukuran kinerja menurut (T.R. Mitchell ,1989 dalam Yunus 2012) dapat dilihat dari empat hal, yaitu:

1. Quality of work yaitu kualitas hasil kerja

2. Promptness yaitu ketepatan waktu menyelesaikan pekerjaan

3. Initiative yaitu prakarsa dalam menyelesaikan pekerjaan

4. Capability yakni kemampuan menyelesaikan pekerjaan.

5. Comunication yaitu kemampuan membina kerjasama dengan pihak lain.

Pengukuran kinerja adalah proses di mana organisasi menetapkan parameter hasil untuk dicapai oleh program, investasi, dan akusisi yang dilakukan. Proses pengukuran kinerja seringkali membutuhkan penggunaan bukti statistik untuk menentukan tingkat kemajuan suatu organisasi dalam meraih tujuannya. Tujuan mendasar di balik dilakukannya pengukuran adalah untuk meningkatkan kinerja secara umum. (Wikipedia, 2016).

Berikut adalah alasan mengapa organisasi mengadopsi pengukuran kinerja (Behn, 2003)

\section{Untuk Mengevaluasi}

Yakni untuk mengevaluasi seberapa baik suatu organisasi berkinerja. Proses evaluasi ini terdiri dari dua variabel: data kinerja organisasi dan patokan yang menciptakan suatu kerangka untuk menganalisis data kinerja tersebut.

2. Untuk Mengendalikan

Manajer memiliki kebutuhan untuk memastikan bahwa bawahan mereka telah melakukan pekerjaan mereka secara benar. Organisasi pun menciptakan sistem pengukuran yang menentuan tindakan tertentu apa yang harus dilakukan oleh karyawan. Setelah itu, mereka pun mengevaluasi apakah sang karyawan betulbetul telah melakukan apa yang telah ditugaskan kepada mereka dan membandingkannya dengan standar kinerja.

3. Untuk Menganggarkan

Anggaran adalah perangkat mentah untuk meningkatkan kinerja. Kinerja yang buruk 
tidak selalu berubah menjadi baik ketika dilakukan pemotongan anggaran sebagai tindakan disipliner. Terkadang penaikan anggaran lah yang menjadi jawaban untuk peningkatan kinerja.

\section{Untuk Memotivasi}

Para karyawan perlu diberikan target yang signifikan untuk mereka raih dan lalu menggunakan ukuran kinerja termasuk target antara untuk memfokuskan ernergi para karyawan dan memberikan perasaan telah mencapai sesuatu. Target kinerja juga bisa mendorong munculnya kreativitas dalam mengembangkan cara-cara yang lebih baik untuk mencapai suatu tujuan.

\section{Untuk Merayakan}

Organisasi perlu memperingati prestasiprestasi yang mereka raih, karena ritual semacam peringatan ini bisa mengikat orangorang yang ada di dalam tim, memberikan mereka perasaan terikat. Perayaan merupakan aktivitas yang mengeksplisitkan pengakuan atas prestasi dan pencapaian.

6. Untuk Bisa Belajar

Pembelajaran merupakan suatu hal yang dibutuhkan oleh organisasi untuk bisa terus berkembang. Pembelajaran ini bisa didapat dengan mengevaluasi kinerja sendiri, semisal dengan mengidentifikasi apa-apa saja yang berhasil dan yang tidak. Dengan mengevaluasi hal ini, organisasi akan bisa pelajari alasan di balik kinerja baik dan buruk.

\section{Untuk Mengembangkan}

Organisasi harus belajar tentang apa-apa yang harus dilakukan secara berbeda untuk memperbaiki kinerja. Oleh karenanya organisasi membutuhkan umpan balik untuk menilai kesesuaian rencana dan arahan serta target sehingga bisa didapatkan pengertian mana-mana

saja perihal yang perlu diperbaiki dan dikembangkan.

Prinsip Pengukuran Kinerja yakni sebagai berikut

1. Seluruh aktivitas kerja yang signifikan harus diukur

2. Pekerjaan yang tidak diukur atau dinilai tidak dapat dikelola karena darinya tidak ada informasi yang bersifat obyektif untuk menentukan nilainya

3. Kerja yang tak diukur selayaknya diminimalisir atau bahkan ditiadakan

4. Keluaran kinerja yang diharapkan harus ditetapkan untuk seluruh kerja yang diukur

5. Hasil keluaran menyediakan dasar untuk menetapkan akuntabilitas hasil alih-alih sekadar mengetahui tingkat usaha
6. Mendefinisikan kinerja dalam artian hasil kerja semacam apa yang diinginkan adalah cara manajer dan pengawas untuk membuat penugasan kerja dari mereka menjadi operasional

7. Pelaporan kinerja dan analisis variansi harus dilakukan secara kerap

8. Pelaporan yang kerap memungkinkan adanya tindakan korektif yang segera dan tepat waktu

9. Tindakan korektif yang tepat waktu begitu dibutuhkan untuk manajemen kendali yang efektif.

Dalam tinjauan ekstensif dari literatur kinerja, terdapat 16 sistem pengukuran kinerja yang berbeda di setiap organisasi. Kelompok peran sistem ini dibagi menjadi lima kategori besar yaitu (1) mengukur kinerja, termasuk kemajuan monitoring, mengukur dan mengevaluasi kinerja; (2) strategy management, yang meliputi perencanaan, strategi formulasi/pelaksanaan/eksekusi, perhatian fokus, dan keselarasan; (3) internal dan eksternal komunikasi, benchmarking, dan sesuai dengan peraturan; (4) mempengaruhi perilaku, yang terdiri perilaku bermanfaat, mengelola hubungan, dan kontrol; dan (5) pembelajaran dan peningkatan, menangkap umpan balik (feedback), dan peningkatan kinerja (FrancoSantos et al., 2007 dalam Speklé dan Verbeeten 2013).

Akuntabilitas kinerja adalah kewajiban untuk menjawab dari perorangan, badan hukum atau pimpinan kolektif secara transparan mengenai keberhasilan atau kegagalan dalam melaksanakan misi organisasi kepada pihak-pihak yang berwenang menerima pelaporan akuntabilitas/pemberi amanah (LKIP, 2015).

Akuntabilitas Kinerja Instansi Pemerintah adalah perwujudan kewajiban suatu instansi pemerintah untuk mempertanggungjawabkan keberhasilan atau kegagalan pelaksanaan visi dan misi organisasi dalam mencapai tujuan dan sasaran yang telah ditetapkan melalui alat pertanggungjawaban secara periodik (LAKIP, 2014).

Berdasarkan Laporan Akuntabilitas Kinerja Instansi Pemerintah (2014), evaluasi bertujuan agar diketahui pencapaian realisasi, kemajuan dan kendala yang dijumpai dalam rangka pencapaian misi, agar dapat dinilai dan dipelajari guna perbaikan pelaksanaan program/kegiatan di masa yang akan datang. Selain itu, dalam evaluasi kinerja dilakukan pula analisis efisiensi dengan cara membandingkan antara output dengan input baik untuk rencana maupun realisasi. Analisis ini menggambarkan tingkat efisiensi yang dilakukan oleh instansi dengan memberikan data nilai output per unit yang dihasilkan oleh suatu input tertentu. Selanjutnya dilakukan pula pengukuran/penentuan tingkat efektivitas yang menggambarkan tingkat kesesuaian antara tujuan dengan hasil, manfaat atau dampak. Selain itu, 
evaluasi juga dilakukan terhadap setiap perbedaan kinerja (performance gap) yang terjadi, baik terhadap penyebab terjadinya gap maupun strategi pemecahan masalah yang telah dan akan dilaksanakan.

Dalam melakukan evaluasi kinerja, perlu juga digunakan pembandingan - pembandingan antara:

1. Kinerja nyata dengan kinerja yang direncanakan.

2. Kinerja nyata dengan kinerja tahun-tahun sebelumnya.

3. Kinerja suatu instansi dengan kinerja instansi lain yang unggul di bidangnya ataupun dengan kinerja sektor swasta.

4. Kinerja nyata dengan kinerja di negaranegara lain atau dengan standar Internasional

Orientasi insentif digunakan untuk memeriksa dampak dari New Public Management dengan menggunakan sistem pengukuran kinerja. Program New Public Management menekankan peran kinerja sistem pengukuran dalam pengaturan sasaran, pemberian insentif. (Newberry dan Pallot, 2004 dalam Speklé dan Verbeeten 2013). Dua karakteristik umum dari pemikiran New Public Management adalah pengenalan rasionalitas ekonomi dan efisiensi sebagai prinsip-prinsip yang menyeluruh, dan keyakinan dalam efek menguntungkan dari praktek manajemen seperti bisnis dan instrumen termasuk praktek pengukuran kinerja (Bogt et al., 2010 dalam Speklé dan Verbeeten 2013).

Menurut Speklé dan Verbeeten (2013), cara di mana sistem pengukuran kinerja di sektor publik digunakan mempengaruhi kinerja organisasi, dan bahwa efek kinerja ini tergantung pada contractibility. Contractibility meliputi kejelasan tujuan, kemampuan untuk memilih ukuran kinerja yang tidak mengalami distorsi, dan sejauh mana manajer tahu dan mengontrol proses perubahan. Kebanyakan organisasi sektor publik yang menggunakan sistem pengukuran kinerja dengan cara yang sesuai dengan karakteristik kegiatan mereka. Berdasarkan penelitian Speklé dan Verbeeten (2013) menunjukkan bahwa contractibility memoderasi hubungan antara penggunaan insentif berorientasi sistem pengukuran kinerja. Penggunaan sistem pengukuran kinerja untuk tujuan insentif negatif mempengaruhi kinerja organisasi, tetapi efek ini terlalu berat ketika Contractibility tinggi.

\section{Metode Penelitian}

Populasi adalah keseluruhan objek yang karakteristiknya akan diuji (Suliyanto, 2006). Sedangkan Sampel yang baik adalah sampel yang benar-benar dapat digunakan untuk menggambarkan karakteristik populasinya (Suliyanto, 2006). Sampel yang dipilih dari populasi dianggap mewakili keberadaan populasi. Pada penelitian ini yang menjadi populasi adalah seluruh PNS (Pegawai Negeri Sipil) yang bekerja pada satuan perangkat daerah Kota Bandung. Oleh karena objek penelitian pada penelitian ini adalah Dinas Pemakaman \& Pertamanan (Jalan Ambon No.1A); Dinas Kependudukan \& Pencatatan Sipil (Jalan Ambon No.1); dan Dinas Pemuda dan Olahraga (Jalan Aceh), maka populasi akan mencakup seluruh PNS yang bekerja pada bagian tersebut.

Pengujian yang dilakukan atas instrumen penelitian (kuesioner) terdiri dari pengujian validitas dan reliabilitas.

Menurut Suliyanto (2009), terdapat dua teknik pengujian data untuk jenis data primer yaitu:

1. Uji Validitas.

Uji validitas digunakan untuk mengukur sah atau valid tidaknya suatu kuesioner. Suatu kuesioner dikatakan valid jika pertanyaan pada kuesioner mampu untuk mengungkapkan sesuatu yang akan diukur oleh kuesioner tersebut (Ghozali, 2013). Peneliti menggunakan Confirmatory Factor Analysis (CFA) untuk menguji validitas data. Analisis faktor konfirmatori digunakan untuk menguji apakah suatu konstruk mempunyai unidimensionalitas atau apakah indikatorindikator yang digunakan dapat mengkonfirmasikan sebuah konstruk atau variabel (Ghozali, 2013).

2. Uji Realibilitas

Instrumen yang reliabel adalah instrumen yang bila digunakan beberapa kali untuk mengukur objek yang sama, akan menghasilkan data yang sama (Sugiono dalam Handayani 2014). Jawaban responden terhadap pertanyaan ini dikatakan reliabel jika masing-masing pertanyaan dijawab secara konsisten atau jawaban tidak boleh acak oleh karena masing-masing pertanyaan hendak mengukur hal yang sama (Ghozali, 2009). Pengujian reliabilitas menggunakan teknik koefisien Cronbach Alpha dengan bantuan SPSS 20. Cronbach Alpha adalah koefisien keandalan yang menunjukkan seberapa baik item dalam suatu kumpulan secara positif berkorelasi satu sama lain (Sekaran dalam Salsalina, 2012). Suatu konstruk atau variabel dikatakan reliabel jika memberikan nilai Cronbach Alpha $>0,60$.

\section{Uji Asumsi Klasik}

Uji asumsi klasik adalah persyaratan statistik yang harus dipenuhi pada analisis regresi linear yang berbasis Ordinary Least Square (Priyanto, 2008). Sebelum dilaksanakan uji asumsi klasik, diperlukan uji normalitas. 


\section{Uji Normalitas}

Menurut Santoso (2001) uji normalitas bertujuan untuk menguji apakah sampel penelitian merupakan jenis distribusi normal. Peneliti menggunakan analisis grafik untuk melihat normalitas, dengan melihat grafik histogram yang membandingkan antara data observasi dengan distribusi yang mendekati distribusi normal (Ghozali, 2013).

\section{Uji Multikolinearitas}

Uji multikolinearitas adalah untuk melihat ada atau tidaknya korelasi yang tinggi antara variabel-variabel bebas dalam suatu model regresi linear berganda. Jika ada korelasi yang tinggi di antara variabel-variabel bebasnya, maka hubungan antara variabel bebas terhadap variabel terikatnya menjadi terganggu (Sunjoyo dkk., 2013).

Multikolinearitas dapat dilihat dari nilai tolerance dan variance inflaction factor (VIF). Kriteria yang dipakai untuk menunjukkan adanya multikolinearitas adalah nilai tolerance $\leq 0,10$ atau nilai VIF $\geq 10$ (Ghozali, 2013).

\section{Uji Heteroskedastisitas}

Heteroskedastisitas adalah adanya ketidaksamaan varian dari residual untuk semua pengamatan pada model regresi. Dilakukannya uji heteroskedastitas untuk mengetahui adanya penyimpangan dari syaratsyarat asumsi klasik pada model regresi.

Salah satu cara untuk mendeteksi adanya heteroskedastisitas adalah menggunakan gambar scatterplot. Jika ada pola tertentu, seperti titik-titik yang ada membentuk pola tertentu yang teratur, maka mengindikasikan telah terjadi heterokedastisitas (Ghozali, 2013).

\section{Uji MRA (Moderated Regression Analysis)}

Variabel moderating adalah variable independen yang berfungsi menguatkan atau melemahkan hubungan antara variabel independen terhadap variabel dependen. Ada beberapa cara untuk menguji regresi dengan variabel moderating dan salah satunya adalah Moderated Regression Analysis (MRA). Moderated Regression Analysis (MRA) atau uji interaksi merupakan aplikasi khusus regresi berganda linear dimana dalam persamaan regresinya mengandung unsur interaksi (perkalian dua atau lebih variabel independen) (Liana Lie, 2009).

\section{Hasil Penelitian dan Pembahasan}

\section{Sampel Penelitian}

Data yang terkumpul dari penelitian ini terdapat 56 kuesioner yang kembali yang diperoleh peneliti dari seluruh PNS (Pegawai Negeri Sipil) yang bekerja pada satuan perangkat daerah Kota Bandung, yaitu Dinas Pemakaman \& Pertamanan (Jalan Ambon No.1A); Dinas Kependudukan \& Pencatatan Sipil
(Jalan Ambon No.1); dan Dinas Pemuda dan Olahraga (Jalan Aceh). Tetapi hanya 54 kuesioner yang dapat diolah, karena pengisian kuesioner yang tidak lengkap oleh dua orang responden.

\section{Hasil Uji Validitas}

Berdasarkan pengolahan spss, terdapat 5 item pertanyaan yang valid, sedangkan 2 pertanyaan tidak valid. Berikut ini hasil uji validitas untuk variabel sistem penilaian kinerja berorientasi insentif (X1):

Tabel 1

Hasil Uji Validitas Sistem Penilaian Kinerja Berorientasi Insentif (X1)

\begin{tabular}{|c|c|c|c|}
\hline $\begin{array}{c}\text { Item } \\
\text { Pertanyaan }\end{array}$ & Kriteria & Hasil & Kesimpulan \\
\hline $\mathrm{X} 11$ & $>0,40$ & 0,438 & Tidak Valid \\
\hline $\mathrm{X} 12$ & $>0,40$ & 0,703 & Valid \\
\hline $\mathrm{X} 13$ & $>0,40$ & 0,627 & Valid \\
\hline $\mathrm{X} 15$ & $>0,40$ & 0,610 & Valid \\
\hline $\mathrm{X} 17$ & $>0,40$ & 0,506 & Valid \\
\hline
\end{tabular}

Berdasarkan hasil pengujian validitas, hanya 2 item pertanyaan yang valid dari 4 pertanyaan. Berikut ini hasil uji validitas untuk variabel sistem penilaian kinerja berorientasi eksplorasi (X2):

Tabel 2

Hasil Uji Validitas Sistem Penilaian Kinerja Berbasis Eksplorasi (X2)

\begin{tabular}{|c|c|c|c|}
\hline $\begin{array}{c}\text { Item } \\
\text { Pertany } \\
\text { aan }\end{array}$ & $\begin{array}{c}\text { Krite } \\
\text { ria }\end{array}$ & $\begin{array}{c}\text { Has } \\
\text { il }\end{array}$ & $\begin{array}{c}\text { Kesimp } \\
\text { ulan }\end{array}$ \\
\hline $\mathrm{X} 21$ & $>$ & 0,6 & Valid \\
& 0,40 & 73 & \\
\hline $\mathrm{X} 24$ & $>$ & 0,5 & Valid \\
& 0,40 & 81 & \\
\hline
\end{tabular}

Berdasarkan pengujian validitas, hanya 1 item pertanyaan yang tidak valid dari 5 pertanyaan. Berikut ini hasil uji validitas untuk variabel kontrakbilitas (X3):

Tabel 3

Hasil Uji Validitas Kontrakbilitas (X3)

\begin{tabular}{|c|c|c|c|}
\hline $\begin{array}{c}\text { Item } \\
\text { Pertanyaan }\end{array}$ & Kriteria & Hasil & Kesimpulan \\
\hline X32 & $>0,40$ & 0,754 & Valid \\
\hline X33 & $>0,40$ & 0,824 & Valid \\
\hline X34 & $>0,40$ & 0,867 & Valid \\
\hline X35 & $>0,40$ & 0,804 & Valid \\
\hline X36 & $>0,40$ & 0,665 & Valid \\
\hline
\end{tabular}

Berdasarkan pengujian validitas variabel Y, hanya 11 item pertanyaan dinyatakan valid dari 33 pertanyaan. Berikut ini hasil uji validitas untuk variabel kinerja (Y): 
Tabel 4

Hasil Uji Validitas Kinerja (Y)

\begin{tabular}{|c|c|c|c|}
\hline $\begin{array}{c}\text { Item } \\
\text { Pertanyaan }\end{array}$ & $\begin{array}{c}\text { Kriteria } \\
\text { (taraf } \\
\text { sig.) }\end{array}$ & Hasil & Kesimpulan \\
\hline Y5 & $>0,40$ & 0,410 & Valid \\
\hline Y10 & $>0,40$ & 0,464 & Valid \\
\hline Y17 & $>0,40$ & 0,667 & Valid \\
\hline Y18 & $>0,40$ & 0,743 & Valid \\
\hline Y21 & $>0,40$ & 0,469 & Valid \\
\hline Y23 & $>0,40$ & 0,623 & Valid \\
\hline Y24 & $>0,40$ & 0,465 & Valid \\
\hline Y25 & $>0,40$ & 0,742 & Valid \\
\hline Y26 & $>0,40$ & 0,583 & Valid \\
\hline Y28 & $>0,40$ & 0,663 & Valid \\
\hline Y31 & $>0,40$ & 0,589 & Valid \\
\hline
\end{tabular}

Hasil Uji Reliabilitas

Hasil uji Reliabilitas untuk semua variabel adalah sebagai berikut:

Tabel 5

Hasil Uji Reliabilitas Sistem Penilaian Kinerja Berorientasi Insentif (X1)

Reliability Statistics

\begin{tabular}{|r|r|}
\hline $\begin{array}{c}\text { Cronbach's } \\
\text { Alpha }\end{array}$ & N of Items \\
\hline .713 & 5 \\
\hline
\end{tabular}

Tabel 6

Hasil Uji Reliabilitas Sistem Penilaian Kinerja Berbasis Eksplorasi (X2)

Tabel 7

Hasil Uji Reliabilitas Kontrakbilitas (X3)

Reliability Statistics

\begin{tabular}{|c|c|}
\hline $\begin{array}{c}\text { Cronbach's } \\
\text { Alpha }\end{array}$ & $\mathrm{N}$ of Items \\
\hline .889 & 5 \\
\hline $\begin{array}{r}\text { Tabel } \\
\text { Hasil Uji Reliabili }\end{array}$ & Cinerja $(Y)$ \\
\hline \multicolumn{2}{|c|}{ Reliability Statistics } \\
\hline $\begin{array}{c}\text { Cronbach's } \\
\text { Alpha }\end{array}$ & $\mathrm{N}$ of Items \\
\hline .852 & 11 \\
\hline
\end{tabular}

Berdasarkan semua data diatas, maka semua variabel dinyatakan reliabel. Untuk variabel X1, X2, X3, dan $\mathrm{Y}$ dinyatakan reliabel karena hasilnya menunjukkan nilai cronbach's alpha di atas 0,60 .

\section{Hasil Uji Normalitas}

Peneliti menggunakan uji normalitas dengan menggunakan grafik histogram. Berikut ini hasil gambar grafik yang diperoleh berdasarkan data yang ada:

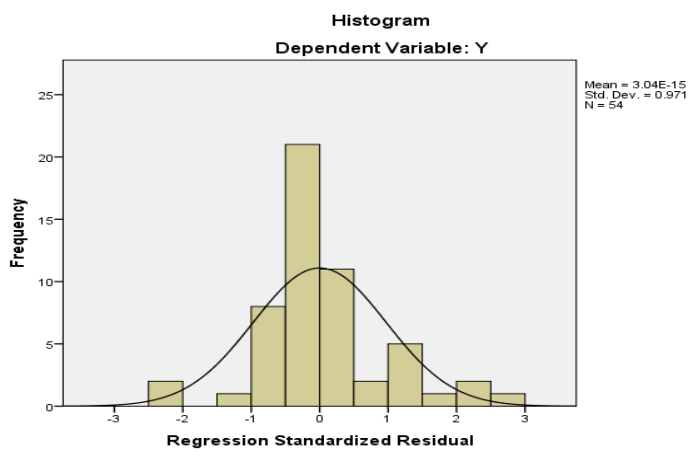

Gambar 1

Hasil Uji Normalitas dengan Grafik

Berdasarkan gambar di atas, dapat terlihat bahwa gambar grafik mendekati normal, sehingga dapat dikatakan model penelitian memiliki distribusi normal.

\section{Hasil Uji Multikolinearitas}

Berdasarkan hasil pengujian multikolinearitas, diperoleh hasil sebagai berikut:

Tabel 9

Hasil Uji Multikolinearitas

\begin{tabular}{|c|c|c|c|c|c|c|c|c|}
\hline & & & & befficients & & & & \\
\hline \multirow{2}{*}{ Mod } & & \multicolumn{2}{|c|}{ Unstandardized Coefficients } & \multirow{2}{*}{$\begin{array}{c}\text { Standardized } \\
\text { Coefficients }\end{array}$} & \multirow[t]{2}{*}{$\mathrm{t}$} & \multirow[t]{2}{*}{ Sig. } & \multicolumn{2}{|c|}{ Collineanity Statistics } \\
\hline & & B & Std. Error & & & & Tolerance & VIF \\
\hline \multirow{4}{*}{1} & (Constant) & 25.699 & 4.699 & & 5.469 & .000 & & \\
\hline & $\mathrm{x} 1$ & .508 & .302 & .232 & 1.679 & .099 & .924 & 1.082 \\
\hline & $\mathrm{x} 2$ & -.050 & .555 & -.012 & -.089 & .929 & .967 & 1.034 \\
\hline & $\mathrm{x} 3$ & 358 & 243 & 202 & 1.475 & .147 & 948 & 1.054 \\
\hline
\end{tabular}

Berdasarkan tabel di atas, maka dapat disimpulkan bahwa tidak terdapat multikolinearitas. Hal ini dapat terlihat dari nilai tolerance yang lebih besar dari 0,1 dan nilai VIF yang lebih kecil dari 10 .

\section{Hasil Uji Heterokedastisitas}

Peneliti menggunakan gambar scatterplot untuk menentukan apakah terdapat heterokedastisitas atau tidak. Berdasarkan gambar 2 dapat terlihat bahwa model penelitian terbebas dari heterokedastisitas karena tidak membentuk pola tertentu. Berikut ini hasil gambar scatterplot yang diperoleh: 


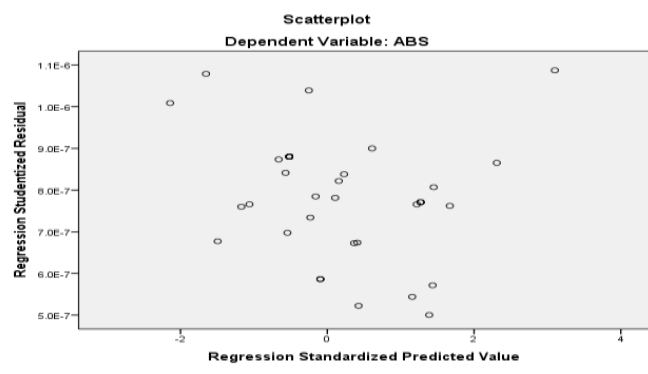

Gambar 2

Hasil Uji Heterokedastisitas

Hasil Uji Hipotesis

Hasil Uji Pengaruh Sistem Penilaian Kinerja Berorientasi Insentif terhadap Kinerja PNS SKPD di Kota Bandung

Berikut ini hasil pengujian hipotesis Sistem penilaian kinerja berorientasi insentif (X1) terhadap kinerja (Y)

Tabel 10

Hasil Uji Regresi Hipotesis 1

\begin{tabular}{|l|r|r|r|c|}
\hline Model & \multicolumn{1}{|c|}{ Model Summary } \\
\hline 1 & $.275^{\mathrm{a}}$ & .076 & \multicolumn{1}{c|}{$\begin{array}{c}\text { R Square } \\
\text { Square }\end{array}$} & $\begin{array}{c}\text { Std. Error of the } \\
\text { Estimate }\end{array}$ \\
\hline
\end{tabular}

a. Predictors: (Constant), X1

b. Dependent Variable: $Y$

\begin{tabular}{|c|c|c|c|c|c|c|}
\hline Model & & Sum of Squares & $\mathrm{df}$ & Mean Square & $\mathrm{F}$ & Sig. \\
\hline \multirow{3}{*}{1} & Regression & 117.772 & 1 & 117.772 & 4.268 & $.044^{\mathrm{b}}$ \\
\hline & Residual & 1434.982 & 52 & 27.596 & & \\
\hline & Total & 1552.753 & 53 & & & \\
\hline
\end{tabular}

a. Dependent Variable: $Y$

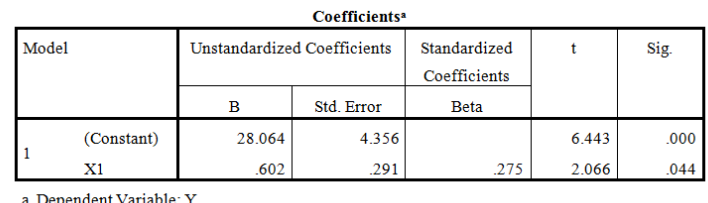

Berdasarkan tabel di atas, dapat terlihat bahwa nilai signifikansi sebesar $0,044<0,05$ sehingga hipotesis diterima, berarti sistem penilaian kinerja berorientasi insentif berpengaruh terhadap kinerja PNS SKPD di Kota Bandung. Sistem penilaian kinerja berorientasi insentif berpengaruh sebesar 7,6\% terhadap kinerja PNS SKPD di Kota Bandung, sisanya faktor lain yang mempengaruhi kineja PNS SKPD di Kota Bandung.

Hasil Uji Pengaruh Sistem Penilaian Kinerja Berorientasi Eksplorasi terhadap Kinerja PNS SKPD di Kota Bandung

Berikut ini hasil pengujian hipotesis Sistem penilaian kinerja berorientasi eksplorasi (X2) terhadap kinerja (Y) :
Tabel 11

Hasil Uji Regresi Hipotesis 2 Model Summary

\begin{tabular}{|r|r|r|c|c|}
\hline Model & $\mathrm{R}$ & $\begin{array}{c}\mathrm{R} \\
\text { Squa } \\
\mathrm{re}\end{array}$ & $\begin{array}{c}\text { Adjusted } \\
\mathrm{R} \text { Square }\end{array}$ & $\begin{array}{c}\text { Std. } \\
\text { Error of } \\
\text { the } \\
\text { Estimat } \\
\mathrm{e}\end{array}$ \\
\hline 1 & $.045^{\mathrm{a}}$ & $\begin{array}{r}0.00 \\
2\end{array}$ & -0.017 & 5.459 \\
\hline
\end{tabular}

a. Predictors: (Constant), X2

b. Dependent Variable: Y

ANOVA $^{\mathrm{a}}$

\begin{tabular}{|l|r|r|r|r|r|}
\hline Model & $\begin{array}{c}\text { Sum of } \\
\text { Square } \\
\mathrm{s}\end{array}$ & $\begin{array}{c}\mathrm{d} \\
\mathrm{f}\end{array}$ & $\begin{array}{c}\text { Mea } \\
\mathrm{n} \\
\text { Squa } \\
\mathrm{re}\end{array}$ & $\mathrm{F}$ & Sig. \\
\hline Regressi & 3.121 & 1 & 3.12 & 0.10 & .74 \\
on & & 1 & 5 & $8^{\mathrm{b}}$ \\
& $\begin{array}{r}1549.6 \\
\text { Residual }\end{array}$ & 53 & 29.8 & & \\
& 1552.7 & 5 & 01 & & \\
1 Total & 53 & 3 & & & \\
\hline
\end{tabular}

a. Dependent Variable: Y

b. Predictors: (Constant), X2

Coefficients $^{\mathrm{a}}$

\begin{tabular}{|l|r|r|r|r|r|}
\hline Model & \multicolumn{2}{|c|}{$\begin{array}{c}\text { Unstandard } \\
\text { ized } \\
\text { Coefficient } \\
\text { s }\end{array}$} & $\begin{array}{c}\text { Standard } \\
\text { ized } \\
\text { Coeffici } \\
\text { ents }\end{array}$ & $\mathrm{t}$ & $\begin{array}{c}\text { Sig } \\
\cdot\end{array}$ \\
\cline { 2 - 4 } & $\mathrm{B}$ & $\begin{array}{r}\text { Std. } \\
\text { Err }\end{array}$ & Beta & & \\
\hline (Const & 36.4 & 1.7 & & 21.1 & 0 \\
ant) & 36 & 24 & & 34 & \\
& 0.18 & 0.5 & 0.045 & 0.32 & 0.7 \\
X2 & 4 & 69 & & 4 & 48 \\
\hline
\end{tabular}

a. Dependent Variable: Y

Berdasarkan tabel di atas, dapat terlihat bahwa nilai signifikansi sebesar 0,748>0,05 sehingga hipotesis ditolak, berarti sistem penilaian kinerja berorientasi eksplorasi tidak berpengaruh terhadap kinerja PNS SKPD di Kota Bandung. 
Hasil Uji Pengaruh Sistem Penilaian Kinerja Berorientasi Insentif terhadap Kinerja PNS SKPD di Kota Bandung yang dimediasi variabel Kontrakbilitas

Berikut ini hasil pengujian hipotesis Sistem penilaian kinerja berorientasi insentif (X1) terhadap kinerja (Y) yang dimediasi oleh kontrakbilitas :

Tabel 12

Hasil Uji Regresi Hipotesis 3

\begin{tabular}{|l|c|r|r|c|}
\multicolumn{5}{|c|}{ Model Summary $^{\mathbf{b}}$} \\
\hline Model & $\mathrm{R}$ & $\begin{array}{c}\mathrm{R} \\
\text { Square }\end{array}$ & $\begin{array}{c}\text { Adjusted } \\
\text { R Square }\end{array}$ & $\begin{array}{c}\text { Std. } \\
\text { Error of } \\
\text { the } \\
\text { Estimate }\end{array}$ \\
\hline 1 & $.314^{\mathrm{a}}$ & .099 & .081 & 5.18807 \\
\hline
\end{tabular}

a. Predictors: (Constant), X1xX3

b. Dependent Variable: Y

ANOVA ${ }^{\mathrm{a}}$

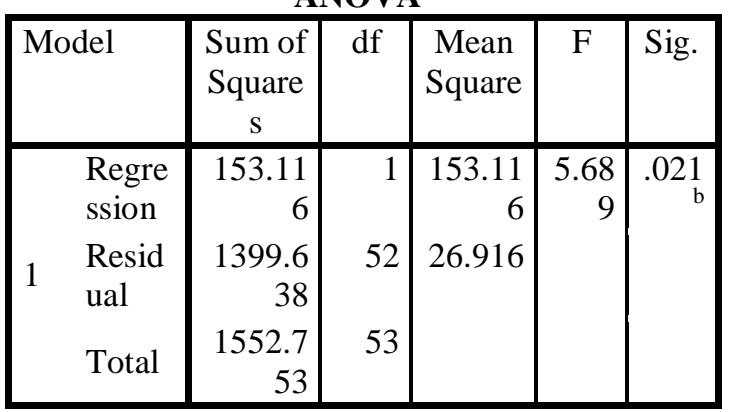

a. Dependent Variable: $\mathrm{Y}$

b. Predictors: (Constant), $\mathrm{X} 1 \mathrm{xX} 3$

\section{Coefficientsa}

\begin{tabular}{|c|c|c|c|c|c|}
\hline \multirow[t]{2}{*}{ Model } & \multicolumn{2}{|c|}{$\begin{array}{c}\text { Unstandardized } \\
\text { Coefficients }\end{array}$} & $\begin{array}{c}\text { Standar } \\
\text { dized }\end{array}$ & \multirow[t]{2}{*}{$\mathrm{t}$} & \multirow[t]{2}{*}{ Sig. } \\
\hline & B & $\begin{array}{l}\text { Std. } \\
\text { Error }\end{array}$ & Beta & & \\
\hline $\begin{array}{l}\text { (Con } \\
\text { stant) }\end{array}$ & 32.347 & 2.051 & & $\begin{array}{r}15.7 \\
72\end{array}$ & .000 \\
\hline $\begin{array}{l}\text { X1x } \\
\text { X3 }\end{array}$ & .028 & .012 & .314 & $\begin{array}{r}2.38 \\
5\end{array}$ & .021 \\
\hline
\end{tabular}

a. Dependent Variable: $\mathrm{Y}$

Berdasarkan tabel di atas, dapat terlihat bahwa nilai signifikansi sebesar $0,021<0,05$ sehingga hipotesis diterima, berarti terdapat pengaruh sistem penilaian kinerja berorientasi insentif terhadap kinerja PNS SKPD di Kota Bandung yang dimediasi oleh variabel kontrakbilitas. Sistem penilaian kinerja berorientasi insentif yang dimediasi kontrakbilitas berpengaruh 9,9\% terhadap kinerja PNS SKPD di Kota Bandung, sisanya kinerja PNS SKPD di Kota Bandung dipengaruhi oleh faktor lain.

Hasil Uji Pengaruh Sistem Penilaian Kinerja Berorientasi Eksplorasi terhadap Kinerja PNS SKPD di Kota Bandung yang dimediasi oleh Kontrakbilitas

Berikut ini hasil pengujian hipotesis Sistem penilaian kinerja berorientasi eksplorasi (X2) terhadap kinerja (Y) yang dimediasi oleh kontrakbilitas :

Tabel 13.

Hasil Uji Regresi Hipotesis 4

Model Summary ${ }^{\mathrm{b}}$

\begin{tabular}{|r|c|r|r|r|}
\hline Model & $\mathrm{R}$ & $\begin{array}{c}\mathrm{R} \\
\text { Square }\end{array}$ & $\begin{array}{c}\text { Adjusted R } \\
\text { Square }\end{array}$ & $\begin{array}{c}\text { Std. Error of } \\
\text { the Estimate }\end{array}$ \\
\hline 1 & $.195^{\mathrm{a}}$ & 0.038 & 0.019 & 5.35977 \\
\hline
\end{tabular}

a. Predictors: (Constant), $\mathrm{X} 2 \mathrm{xX} 3$

b. Dependent Variable: Y

ANOVA $^{\mathrm{a}}$

\begin{tabular}{|l|r|r|r|r|l|}
\hline Model & $\begin{array}{c}\text { Sum of } \\
\text { Squares }\end{array}$ & df & $\begin{array}{c}\text { Mean } \\
\text { Squar } \\
\text { e }\end{array}$ & F & Sig. \\
\hline Regression & 58.942 & 1 & 58.942 & 2.052 & $.158^{\mathrm{b}}$ \\
& 1493.811 & 5 & 28.727 & & \\
& Residual & 2 & & & \\
& & & & \\
1 Total & 1552.753 & 5 & & & \\
\hline
\end{tabular}

a. Dependent Variable: Y

b. Predictors: (Constant), X2xX3

Coefficients $^{\mathrm{a}}$

\begin{tabular}{|c|c|c|c|c|c|}
\hline \multirow[t]{2}{*}{ Model } & \multicolumn{2}{|c|}{$\begin{array}{l}\text { Unstandardized } \\
\text { Coefficients }\end{array}$} & $\begin{array}{l}\text { Standa } \\
\text { rdized }\end{array}$ & \multirow[t]{2}{*}{$\mathrm{t}$} & \multirow[t]{2}{*}{ Sig. } \\
\hline & B & $\begin{array}{l}\text { Std. } \\
\text { Error }\end{array}$ & Beta & & \\
\hline Constant & $\begin{array}{r}35.44 \\
8\end{array}$ & 1.271 & & $\begin{array}{r}27.88 \\
3\end{array}$ & $\overline{0}$ \\
\hline $1 \quad \mathrm{X} 2 \times \mathrm{X} 3$ & 0.05 & 0.035 & 0.195 & 1.432 & 0.158 \\
\hline
\end{tabular}

a. Dependent Variable: Y

Berdasarkan tabel di atas, dapat terlihat bahwa nilai signifikansi sebesar $0,158>0,05$ sehingga hipotesis ditolak, berarti tidak ada pengaruh sistem penilaian kinerja berorientasi eksplorasi terhadap kinerja PNS SKPD di Kota Bandung yang dimediasi oleh variabel kontrakbilitas. 


\section{Pembahasan Hasil Pengujian Hipotesis}

Berdasarkan pengujian hipotesis diatas, dapat disimpulkan bahwa sistem penilaian kinerja berorientasi insentif berpengaruh terhadap kinerja PNS SKPD di Kota Bandung, baik dimediasi oleh kontrakbilitas ataupun tidak. Hasil pengujian ini sejalan dengan penelitian Speklé dan Verbeeten (2013) yang menunjukkan bahwa contractibility memoderasi hubungan antara penggunaan insentif berorientasi sistem pengukuran kinerja.

\section{Simpulan dan Saran}

\section{Simpulan}

Berdasarkan hasil penelitian yang telah dibahas di bab empat, maka peneliti membuat kesimpulan sebagai berikut:

1. Sistem penilaian kinerja berorientasi insentif berpengaruh terhadap kinerja PNS SKPD di Kota Bandung. Besarnya pengaruh kinerja berorientasi insentif terhadap kinerja PNS SKPD di Kota Bandung sebesar 7,6\%.

2. Sistem penilaian kinerja berorientasi eksplorasi tidak berpengaruh terhadap kinerja PNS SKPD di Kota Bandung.

3. Terdapat pengaruh antara sistem penilaian kinerja berorientasi insentif terhadap kinerja PNS SKPD di Kota Bandung yang dimediasi oleh variabel contractibility. Besarnya pengaruh penilaian kinerja berorientasi insentif yang dimediasi kontrakbilitas terhadap kinerja PNS SKPD di Kota Bandung sebesar 9,9\%.

4. Tidak terdapat pengaruh antara sistem penilaian kinerja berorientasi eksplorasi terhadap kinerja PNS SKPD di Kota Bandung yang dimediasi oleh variabel contractibility.

\section{Saran}

Peneliti menemukan beberapa keterbatasan dalam melakukan penelitian, sehingga peneliti mengemukakan beberapa saran sebagai berikut:

1. Jumlah sampel sebaiknya diperluas di beberapa SKPD di Kota Bandung. Keterbatasan jumlah sampel PNS SKPD di Kota Bandung yang diperoleh peneliti, sehingga mempengaruhi hasil pengolahan data peneliti.

2. Penelitian selanjutnya dapat menambah variabel lain yang mempengaruhi kinerja PNS SKPD di Kota Bandung, selain penilaian kinerja berorientasi insentif, penilaian kinerja berorientasi eksplorasi, maupun kontrakbilitas.

\section{Daftar Pustaka}

Agustina, Vina dan Yoestini. 2012. Analisis Pengaruh Kualitas Pelayanan, Kepuasan Pelanggan, dan Nilai Pelanggan dalam Meningkatkan Loyalitas Pelanggan Joglosemar Bus. Diponegoro Journal of Management. Vol 1, No.1, hal. 1-11.

Laporan Akuntabilitas Kinerja Instansi Pemerintah. 2014. Inspektorat Kota Bandung. www.inspektorat.bandung.go.id.

Laporan Kinerja Instansi Pemerintah Kecamatan Rancasari. 2014. Lie Liana. 2009. Penggunaan MRA dengan SPSS untuk Menguji Pengaruh Variabel Moderating terhadap Hubungan antara Variabel Independen dan Variabel Dependen. Jurnal Teknologi Informasi DINAMIK Vol.2. Juli 2009. pp. 90-97.

Ghozali, Imam. 2013. Aplikasi Analisis Multivariate dengan Program IBM SPSS 21 Update PLS Regresi. Cetakan Ketujuh. Semarang: Badan Penerbit Universitas Diponegoro

Hartono. 2011. Metodologi Penelitian. Zanafa Publishing. Pekanbaru. https://id.wikipedia.org/ wiki/Pengukuran_kinerja.

Priyanto, Dwi. 2008. Mandiri Belajar SPSS. Mediakom. Yogyakarta.

Spekle, Roland F. and Frank H.M. Verbeeten. 2014. The Use of Performance Measurement Systems in The Public Sector: Effects on Performance. Management Accounting Research. Volume 12, Issue 2, June 2014, Pages 131-146.

Speklé dan Verbeeten. 2013. The use of performance measurement systems in the public sector: Effects on performance, Management Accounting Research, 507, 1-16.

Sugiyono. 2011. Metode Penelitian Pendidikan. Alfabeta. Bandung.

Suliyanto. 2006. Metode Riset Bisnis. Penerbit Andi. Yogyakarta.

Sunjoyo, dkk. 2013. Aplikasi SPP Untuk Smart Riset. Alfabeta. Bandung.

Sutrisno, Prihatin. 2007. Sistem Pengukuran dan Penilaian Kinerja Karyawan Dalam Menjalankan Tugas dan Kewajibannya. Bandung.

Robert D. Behn 2003. Why measure Performance? Different Purposes Require Different Measures.

Yunus, Dalifah. 2012. Pengaruh Kinerja Guru Terhadap Kualitas Pembelajaran IPA SMP di Kabupaten Belitung Timur. Jakarta. 


\section{KUESIONER PENELITIAN}

Kepada Yth.

Bapak/Ibu/Saudara/Saudari Responden di tempat

Kami peneliti dari Universitas Kristen Maranatha Bandung, bersama ini dengan hormat memohon kesediaan Bapak/Ibu/Saudara/Saudari untuk menjadi responden dalam penelitian kami. Penelitian kami berjudul: Pengaruh Sistem Penilaian Kinerja Terhadap Kinerja PNS Satuan Kerja Perangkat Daerah Kota Bandung dengan Contractibility sebagai Variabel Moderating. Peneliti memohon kesediaan Bapak/Ibu/Saudara/Saudari untuk mengisi kuesioner ini sesuai dengan persepsi Bapak/Ibu/Saudara/Saudari. Semua informasi yang diperoleh akan menjadi sebuah penelitian secara akademis. Sesuai dengan etika penelitian, peneliti akan menjaga kerahasiaan tanggapan Bapak/Ibu/Saudara/Saudari. Keberhasilan penelitian ini sangat bergantung pada partisipasi Bapak/Ibu/Saudara/Saudari. Atas dukungan dan partisipasinya, peneliti ucapkan terima kasih.

Hormat kami,

Peneliti

1. Endah Purnama Sari, S.E., M.Ak., Ak., BKP., CA

2. Santy Setiawan, S.E., M.Si., Ak., CA.

3. Alif Rifky A

\section{DATA RESPONDEN}

Nama:

(boleh diisi/tidak)

Jenis Kelamin: ( ) 1.Laki-laki ( ) 2.Perempuan

Usia: tahun

Lama Bekerja: ....tahun

Bagian:

\section{Petunjuk Pengisian:}

1. Isilah semua pernyataan yang disajikan dalam kuesioner ini.

2. Setiap pernyataan hanya dapat ditanggapi dengan cara memilih satu skor yang ada di setiap kolom sesuai persepsi Bapak/Ibu/Saudara/Saudari

3. Berikan tanda silang pada skor yang mewakili persepsi Bapak/Ibu/Saudara/Saudari.

Keterangan:

STS: $\quad$ Sangat Tidak Setuju

TS: $\quad$ Tidak Setuju
KS: Kurang Setuju

S: Setuju

SS: $\quad$ Sangat Setuju

\begin{tabular}{|c|c|c|c|c|c|c|}
\hline No. & $\begin{array}{c}\text { Penyataan-pernyataan ini } \\
\text { bertujuan untuk } \\
\text { mengetahui Kinerja SKPD }\end{array}$ & STS & TS & $\mathbf{N}$ & $\mathbf{S}$ & SS \\
\hline 1. & $\begin{array}{l}\text { Visi dan Misi organisasi } \\
\text { dibuat dengan mengacu pada } \\
\text { UU No. 25 Tahun } 2009 \\
\text { tentang pelayanan publik. }\end{array}$ & & & & & \\
\hline 2. & $\begin{array}{l}\text { Visi dan Misi organisasi } \\
\text { dijabarkan dalam } \\
\text { kerja (renja) dan } \\
\text { strategi organisasi (renstra). }\end{array}$ & & & & & \\
\hline 3. & $\begin{array}{l}\text { Motto pelayanan organisasi } \\
\text { mampu memotivasi pegawai } \\
\text { untuk memberikan pelayanan } \\
\text { yang terbaik. }\end{array}$ & & & & & \\
\hline 4. & $\begin{array}{l}\text { Motto pelayanan organisasi } \\
\text { diumumkan secara luas } \\
\text { kepada publik/pengguna } \\
\text { layanan (dipajang diruang } \\
\text { pelayanan atau melalui media } \\
\text { massa). }\end{array}$ & & & & & \\
\hline 5. & $\begin{array}{l}\text { Penyusunan, penetapan dan } \\
\text { penerapan standar pelayanan } \\
\text { organisasi mengacu pada UU } \\
\text { No. } 25 \text { Tahun } 2009 \text { tentang } \\
\text { pelayanan publik. }\end{array}$ & & & & & \\
\hline 6. & $\begin{array}{l}\text { Maklumat pelayanan } \\
\text { dipublikasikan kepada publik } \\
\text { (pengguna layanan). }\end{array}$ & & & & & \\
\hline 7. & $\begin{array}{l}\text { Organisasi memiliki sertifikat } \\
\text { ISO 9001:2008 dalam } \\
\text { menyelenggarakan pelayanan } \\
\text { publik. }\end{array}$ & & & & & \\
\hline 8. & \begin{tabular}{lrr}
\multicolumn{2}{l}{ Organisasi menerapkan } \\
Sistem Manajemen Mutu \\
$(\mathrm{SMM})$. & & \\
\end{tabular} & & & & & \\
\hline 9. & $\begin{array}{l}\text { Organisasi menetapkan } \\
\text { Standar Operasional Prosedur } \\
(\mathrm{SOP}) \text {. }\end{array}$ & & & & & \\
\hline 10. & $\begin{array}{l}\text { Organisasi menetapkan uraian } \\
\text { tugas secara jelas. }\end{array}$ & & & & & \\
\hline 11. & $\begin{array}{l}\text { Organisasi menetapkan dan } \\
\text { menerapkan pedoman kode } \\
\text { etik pegawai bagi seluruh } \\
\text { pegawai. }\end{array}$ & & & & & \\
\hline 12. & $\begin{array}{l}\text { Pegawai bersikap dan } \\
\text { berperilaku ramah/baik dalam } \\
\text { memberikan pelayanan } \\
\begin{array}{l}\text { kepada para pengguna } \\
\text { layanan. }\end{array}\end{array}$ & & & & & \\
\hline 13. & $\begin{array}{l}\text { Pegawai memiliki tingkat } \\
\text { kedisplinan } \\
\text { memberikan dalam } \\
\text { kepada pengguna layanan. }\end{array}$ & & & & & \\
\hline 14. & 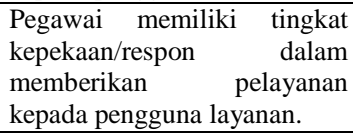 & & & & & \\
\hline 15. & $\begin{array}{l}\text { Pegawai memiliki } \\
\text { keterampilan yang memadai } \\
\text { dalam memberikan pelayanan } \\
\text { kepada pengguna layanan. }\end{array}$ & & & & & \\
\hline 16. & $\begin{array}{l}\text { Terdapat kebijakan } \\
\text { pengembangan pegawai untuk } \\
\text { meningkatkan } \\
\text { keterampilan/profesionalisme } \\
\text { pegawai. }\end{array}$ & & & & & \\
\hline
\end{tabular}




\begin{tabular}{|c|c|c|c|c|c|c|}
\hline No. & $\begin{array}{c}\text { Penyataan-pernyataan } \\
\text { ini bertujuan untuk } \\
\text { mengetahui Kinerja } \\
\text { SKPD } \\
\end{array}$ & STS & TS & $\mathbf{N}$ & $\mathbf{S}$ & SS \\
\hline 17. & $\begin{array}{lr}\text { Sarana dan prasarana yang } \\
\text { dipergunakan untuk proses } \\
\text { pelayanan } & \text { telah } \\
\text { didayagunakan } & \text { secara } \\
\text { optimal. } & \end{array}$ & & & & & \\
\hline 18. & $\begin{array}{l}\text { Sarana dan prasarana } \\
\text { pelayanan yang tersedia } \\
\text { ada dalam kondisi bersih } \\
\text { dan sederhana. }\end{array}$ & & & & & \\
\hline 19. & $\begin{array}{l}\text { Sarana dan prasarana } \\
\text { pelayanan yang tersedia } \\
\text { ada dalam kondisi layak } \\
\text { dan bermanfaat. }\end{array}$ & & & & & \\
\hline 20. & $\begin{array}{lr}\text { Tersedia } & \text { sarana } \\
\text { pengaduan, seperti: } & \text { kotak } \\
\text { pengaduaan, } & \text { loket } \\
\text { pengaduan, telepon, email } \\
\text { dan lain sebagainya. }\end{array}$ & & & & & \\
\hline 21. & $\begin{array}{l}\text { Organisasi memiliki sistem } \\
\text { atau prosedur untuk } \\
\text { mengelola pengaduan dari } \\
\text { pengguna layanan. }\end{array}$ & & & & & \\
\hline 22. & $\begin{array}{l}\text { Dalam organisasi, terdapat } \\
\text { petugas khusus/unit yang } \\
\text { dapat menangani } \\
\text { pengelolaan pengaduan. }\end{array}$ & & & & & \\
\hline 23. & $\begin{array}{l}\text { Setiap pengaduan yang } \\
\text { disampaikan pengguna } \\
\text { layanan dapat diselesaikan } \\
\text { oleh organisasi. }\end{array}$ & & & & & \\
\hline 24. & $\begin{array}{lr}\text { Organisasi mengacu pada } \\
\text { Peraturan Menteri PAN- } \\
\text { RB No. 13 Tahun 2009 } \\
\text { tentang } & \text { Pedoman } \\
\text { Peningkatan } & \text { Kualitas } \\
\text { Pelayanan } & \text { dengan } \\
\text { Partisipasi } & \text { Masyarakat } \\
\text { dalam rangka peningkatan } \\
\text { kualitas pelayanan untuk } \\
\text { mengelola pengaduan dari } \\
\text { pengguna layanan. }\end{array}$ & & & & & \\
\hline 25 & $\begin{array}{l}\text { Organisasi melaksanakan } \\
\text { survei Indeks Kepuasan } \\
\text { Masyarakat (IKM) setiap } \\
\text { periode. }\end{array}$ & & & & & \\
\hline 26. & $\begin{array}{l}\text { Survei IKM yang } \\
\text { dilakukan oleh organisasi } \\
\text { mengacu pada Kepmenpan } \\
\text { Nomor } 25 \text { Tahun } 2004 \text {. }\end{array}$ & & & & & \\
\hline 27. & \begin{tabular}{llll} 
Rata-rata & \multicolumn{3}{c}{ skor IKM yang } \\
diperoleh & \multicolumn{2}{c}{ menunjukkan } \\
kinerja & organisasi & baik \\
$($ diatas & nilai 2,5 & atau \\
$62,50)$. & & \\
\end{tabular} & & & & & \\
\hline 28. & \begin{tabular}{lll} 
Organisasi & \multicolumn{2}{c}{ melakukan } \\
tindak lanjut & atas hasil \\
survei IKM. & & \\
\end{tabular} & & & & & \\
\hline 29. & $\begin{array}{l}\text { Organisasi menggunakan } \\
\text { sistem informasi pelayanan } \\
\text { berbasis elektronik. }\end{array}$ & & & & & \\
\hline 30. & $\begin{array}{l}\text { Penyampaian informasi } \\
\text { pelayanan publik kepada } \\
\text { pengguna layanan dapat } \\
\text { diakses secara online. }\end{array}$ & & & & & \\
\hline
\end{tabular}

\begin{tabular}{|c|c|c|c|c|c|c|}
\hline No. & $\begin{array}{c}\text { Penyataan-pernyataan ini } \\
\text { bertujuan untuk } \\
\text { mengetahui contractibility } \\
\text { (perjanjian kinerja) }\end{array}$ & STS & TS & $\mathbf{N}$ & $\mathbf{S}$ & SS \\
\hline 31. & $\begin{array}{l}\text { Terdapat keterbukaan } \\
\text { informasi pelayanan kepada } \\
\text { pengguna layanan karena } \\
\text { setiap informasi dapat } \\
\text { diakses secara online. }\end{array}$ & & & & & \\
\hline 32. & $\begin{array}{l}\text { Organisasi menetapkan } \\
\text { target kinerja pelayanan. }\end{array}$ & & & & & \\
\hline 33. & $\begin{array}{lrr}\text { Organisasi } & \text { berusaha } \\
\text { mencapai target kinerja } \\
\text { dalam } & \text { menjalankan } \\
\text { pelayanannya. } & \end{array}$ & & & & & \\
\hline 34. & $\begin{array}{l}\text { Organisasi menyusun } \\
\text { rencana kerja dan anggaran } \\
\text { dalam bentuk dokumen. }\end{array}$ & & & & & \\
\hline 35. & $\begin{array}{l}\text { Dokumen rencana kerja dan } \\
\text { anggaran menjadi dasar } \\
\text { penyusunan perjanjian } \\
\text { kinerja. }\end{array}$ & & & & & \\
\hline 36. & $\begin{array}{l}\text { Dokumen perjanjian kinerja } \\
\text { merupakan } \\
\text { lembar/dokumen yang } \\
\text { berisikan penugasan untuk } \\
\text { melaksanakan } \\
\text { program/kegiatan. }\end{array}$ & & & & & \\
\hline 37. & $\begin{array}{l}\text { Dokumen perjanjian kinerja } \\
\text { disusun } \\
\text { mencantumkan indikator } \\
\text { kinerja program/kegiatan } \\
\text { atau indikator kinerja } \\
\text { utama. }\end{array}$ & & & & & \\
\hline 38. & $\begin{array}{l}\text { Dalam dokumen perjanjian } \\
\text { kinerja terdapat target } \\
\text { kinerja organisasi. }\end{array}$ & & & & & \\
\hline 39. & $\begin{array}{l}\text { Dokumen perjanjian kinerja } \\
\text { organisasi disepakati oleh } \\
\text { walikota dan pimpinan } \\
\text { organisasi } \\
\text { SKPD). }\end{array}$ & & & & & \\
\hline 40. & $\begin{array}{l}\text { Organisasi membuat } \\
\text { pembayaran atas kinerja } \\
\text { sebagai bagian integral dan } \\
\text { rencana formal organisasi. }\end{array}$ & & & & & \\
\hline 41. & $\begin{array}{l}\text { Pemberian insentif kepada } \\
\text { pegawai dilakukan } \\
\text { berdasarkan data kinerja } \\
\text { yang akurat dan obyektif. }\end{array}$ & & & & & \\
\hline 42. & $\begin{array}{l}\text { Pegawai dilibatkan dalam } \\
\text { pengembangan, } \\
\text { implementasi, dan revisi } \\
\text { formula pembayaran } \\
\text { kinerja. }\end{array}$ & & & & & \\
\hline 43. & \begin{tabular}{lrr}
\multicolumn{2}{l}{ Organisasi } & \multicolumn{2}{c}{ membangun } \\
sistem pembayaran & untuk \\
rencana kerja & secara \\
konsisten. & & \\
\end{tabular} & & & & & \\
\hline 44. & $\begin{array}{lr}\text { Pemberian } & \text { insentif } \\
\text { kelompok } & \text { kerja dan } \\
\text { individual } & \text { dilakukan } \\
\text { berdasarkan } & \text { kontribusi } \\
\text { kerja. } & \\
& \end{array}$ & & & & & \\
\hline 45. & $\begin{array}{l}\text { Dalam organisasi, terdapat } \\
\text { sistem pengawasan dan } \\
\text { penilaian kinerja yang } \\
\text { transparan. }\end{array}$ & & & & & \\
\hline
\end{tabular}


Jurnal Akuntansi Maranatha - Vol. 9 No. 2, November 2017 : 146 - 157

\begin{tabular}{|c|c|c|c|c|c|c|}
\hline No. & $\begin{array}{c}\text { Penyataan-pernyataan } \\
\text { ini untuk mengetahui } \\
\text { sistem pengukuran } \\
\text { kinerja yang berorientasi } \\
\text { eksplorasi. }\end{array}$ & STS & TS & $\mathbf{N}$ & $\mathbf{S}$ & SS \\
\hline 46. & $\begin{array}{l}\text { Pemberian insentif disertai } \\
\text { dengan penghargaan } \\
\text { (reward) yang dapat } \\
\text { meningkatkan kepuasan } \\
\text { pegawai. }\end{array}$ & & & & & \\
\hline 47. & $\begin{array}{l}\text { Organisasi membuka } \\
\text { kesempatan bagi pegawai } \\
\text { untuk berdiskusi dan } \\
\text { memberikan masukan } \\
\text { berupa ide. }\end{array}$ & & & & & \\
\hline 48 . & $\begin{array}{l}\text { Organisasi melakukan } \\
\text { eksperimen, pembelajaran } \\
\text { dan adaptasi terhadap } \\
\text { pandangan-pandangan } \\
\text { yang baru berkembang. }\end{array}$ & & & & & \\
\hline 49. & $\begin{array}{lr}\text { Pegawai bersedia terlibat } \\
\text { dalam } & \text { perdebatan } \\
\text { organisasi untuk tujuan } \\
\text { perkembangan organisasi } \\
\text { di masa depan dan } \\
\text { menyangkut } & \text { skala } \\
\text { prioritas. } & \end{array}$ & & & & & \\
\hline 50. & $\begin{array}{l}\text { Terdapat interaksi yang } \\
\text { tinggi antar pegawai } \\
\text { (anggota organisasi) di } \\
\text { berbagai jenjang hirarkis } \\
\text { sehingga menuntut adanya } \\
\text { komunikasi dan konsultasi } \\
\text { yang luas. }\end{array}$ & & & & & \\
\hline
\end{tabular}

